Gut, 1985, 26, 1038-1044

\title{
Duodenal ulcer healing by separate reduction of postprandial and nocturnal acid secretions have different pathophysiology
}

\author{
SHIU-KUM LAM, CHING-LUNG LAI, MATTHEW NG, KAI-HING FOK, \\ AND WAI-MO HUI \\ From the Department of Medicine, University of Hong Kong, Queen Mary Hospital, Hong Kong
}

SUMmaRY The endoscopic healing rates and factors related to healing of two cimetidine regimens designed to reduce respectively postprandial and nocturnal acid secretions were studied in a randomised trial of cimetidine $200 \mathrm{mg}$ tds with meals, $v s 600 \mathrm{mg}$ at bedtime, $v s 200 \mathrm{mg}$ tds with meals plus $400 \mathrm{mg}$ at bedtime in 246 patients with duodenal ulcer. The respective healing rates were $62.3 \%, 63.1 \%, 77.5 \%$ at four weeks and $86.6 \%, 83.3 \%, 91.2 \%$ at eight weeks. The healing rates at four weeks of both meal time and bedtime regimens were inferior $(p<0 \cdot 05)$ to that of the standard regimen. Analysis of 45 prospectively obtained factors showed that (i) habitual cigarette smoking adversely affected healing with the meal time regimen but not with the others, indicating that its adverse effect disappeared once nocturnal acid secretion was reduced, (ii) habitual use of analgesics impaired and their abstinence favoured healing by both meal time and bedtime regimens but these effects were lost with the standard regimen, suggesting that if analgesics cannot be withdrawn during ulcer treatment, a reduction of both meal time and night time acid secretions should be ensured, (iii) responders with the meal time and bedtime regimens had respectively significantly higher postprandial serum gastrin and higher basal acid output than the corresponding non-responders suggesting that these responders had different pathophysiology, and (iv) high maximal acid output and large ulcers healed less well by any regimen.

Successful healing of duodenal ulcer can be achieved by giving antacid one and three hours after meals and at bedtime, ${ }^{12}$ a regimen aiming mainly at the reduction of meal stimulated acid secretion. Successful healing can also be obtained by the use of a single bedtime dose of $\mathrm{H}_{2}$-receptor antagonists to control the nocturnal acid secretion. ${ }^{34} \mathrm{~A}$ bedtime dose of $\mathrm{H}_{2}$-receptor antagonists also prevents recurrence of duodenal ulcer. ${ }^{5}$ These meal time and bedtime regimens underscore the importance of meal stimulated as well as nocturnal acid secretions in the pathophysiology of duodenal ulcer.

This study compares the efficacy of a meal time and a bedtime regimen of cimetidine, with reference to a standard regimen of $1 \mathrm{~g}$ daily, in the healing of duodenal ulcer, and examines the relative importance of 45 prospectively obtained factors in their

Address for correspondence: Professor S K Lam, Department of Medicine. University of Hong Kong, Queen Mary Hospital, Hong Kong.

Received for publication 15 November 1984 influence on healing by these regimens.

\section{Methods}

\section{PATIENTS}

Candidates were recruited from patients attending the University Medical Gastrointestinal Clinics as well as patients admitted to the general medical, and gastrointestinal wards of the University Department of Medicine, Queen Mary Hospital, Hong Kong. Candidates were excluded from consideration if they had a concomitant medical problem, particularly renal disease, cardiovascular disease, diabetes mellitus, or chronic obstructive airways; pyloric stenosis; previous gastric operations for ulcers; or an associated gastric ulcer. Informed consent was obtained from each patient.

CLINICAL AND PERSONAL CHARACTERISTICS

After being accepted into the study, the patients 
were interviewed in detail and the clinical and ulcer symptoms at age 30 years below, and late onset personal characteristics as listed in Table 1 were carefully recorded. Further explanation is necessary regarding the following points. Early onset patients as those having the age of onset after 30 years, as based on previous studies. ${ }^{6}$ Pain severity, which was also assessed at subsequent visits, was scored as were defined as those having the age of onset of

follows: nil $=0$, mild $=1$, off work or work

Table 1 Patient characteristics prospectively obtained before commencement of cimetidine treatment. $B A O=$ basal acid output, $M A O=$ maximal acid output, $D_{50 C}=$ dose of pentagastrin for half $M A O$ after correction for $B A O$. Values are expressed as mean $\pm S E$. Asterisk indicates values that were log transformed before statistical analysis.

\begin{tabular}{|c|c|c|c|c|c|}
\hline Characteristics & $\begin{array}{l}\text { Individual } \\
\text { values }\end{array}$ & $\begin{array}{l}\text { Meal time } \\
200 \mathrm{mg} \text { tds } \\
n=82\end{array}$ & $\begin{array}{l}\text { Bedtime } \\
600 \mathrm{mg} \\
n=84\end{array}$ & $\begin{array}{l}\text { Standard } \\
1 \mathrm{~g} \text { daily } \\
n=80\end{array}$ & $\begin{array}{l}p \\
<\end{array}$ \\
\hline \multicolumn{6}{|l|}{ Clinical } \\
\hline Onset age & year & $\begin{array}{l}26 \cdot 8 \pm 1 \cdot 4 \\
59 \cdot 8\end{array}$ & $\begin{array}{l}26 \cdot 0 \pm 1 \cdot 4 \\
56 \cdot 2\end{array}$ & $\begin{array}{l}23 \cdot 5 \pm 1 \cdot 4 \\
55 \cdot 0\end{array}$ & $\begin{array}{l}0.48 \\
0.65\end{array}$ \\
\hline $\begin{array}{l}\text { Early onset ( } \leqslant \text { age } 30 \mathrm{yr} \text { ) } \\
\text { Duration of symptoms }\end{array}$ & $\begin{array}{l}\% \\
\text { year }\end{array}$ & $\begin{array}{l}59 \cdot 8 \\
7 \cdot(0 \pm 0 \cdot 8\end{array}$ & $\begin{array}{r}56 \cdot 2 \\
7 \cdot 7 \pm 0 \cdot 8\end{array}$ & $9 \cdot 2 \pm 1 \cdot 0$ & 0.65 \\
\hline Duration of symptoms & year & $\begin{array}{r}1 \cdot 0 \pm 0 \cdot 0 \\
21 \cdot 4 \pm 4 \cdot 6\end{array}$ & $29 \cdot 2 \pm 6 \cdot 8$ & $26 \cdot 5 \pm 7 \cdot 0$ & $0 \cdot 20$ \\
\hline Current symptom period & day & & $29 \cdot 2 \pm 0 \cdot 8$ & & $0 \cdot 60$ \\
\hline Latest remission period & month & $5 \cdot 5 \pm 0 \cdot 9$ & $6 \cdot 2 \pm 0 \cdot 94$ & $6 \cdot 3 \pm 1 \cdot 5$ & $0 \cdot 88$ \\
\hline Pain score & $0-3$ & $1 \cdot 4 \pm 0 \cdot 1$ & $1 \cdot 4 \pm 0 \cdot 1$ & $1 \cdot 6 \pm 0 \cdot 1$ & 0.42 \\
\hline Average pain duration & hour & $2 \cdot() \pm 1 \cdot 0$ & $1 \cdot 9 \pm 0 \cdot 2$ & $1 \cdot 6 \pm 0.4$ & 0.49 \\
\hline Back pain & $\%$ & $24 \cdot 4$ & $26 \cdot 2$ & $25 \cdot 0$ & 0.94 \\
\hline Nocturnal pain & $\%$ & $63 \cdot 4$ & $67 \cdot 9$ & $57 \cdot 5$ & $0 \cdot 48$ \\
\hline Previous melacna & $\%$ & 49 & 53 & 48 & 0.63 \\
\hline Previous haematemesis & $\%$ & 21 & 13 & 11 & $0 \cdot 19$ \\
\hline \multicolumn{6}{|l|}{ Personal } \\
\hline $\begin{array}{l}\text { Age } \\
\text { Male }\end{array}$ & year & $33 \cdot 5 \pm 1 \cdot 6$ & $32 \cdot 8 \pm 1 \cdot 5$ & $33 \cdot 4 \pm 1 \cdot 8$ & 0.79 \\
\hline $\begin{array}{l}\text { Male } \\
\text { Work stress }\end{array}$ & $\%$ & 63 & 70 & 63 & \\
\hline $\begin{array}{l}\text { Work stress } \\
\text { Neurosis }\end{array}$ & $0-3$ & $0 \cdot 7 \pm 0 \cdot 1$ & $0 \cdot 8 \pm(0 \cdot 1$ & $0 \cdot 9 \pm 0 \cdot 1$ & $0 \cdot 23$ \\
\hline & $0-3$ & $0 \cdot 8 \pm 0 \cdot 1$ & $0 \cdot 9 \pm 0 \cdot 1$ & $0 \cdot 8 \pm 0 \cdot 1$ & $0 \cdot 67$ \\
\hline $\begin{array}{l}\text { Cigarette, non-smoker } \\
<10 / \text { day }\end{array}$ & $\%$ & $54 \cdot 9$ & $\begin{array}{l}53 \cdot 6 \\
17 \cdot 0\end{array}$ & $65 \cdot 0$ & $0 \cdot 27$ \\
\hline $\begin{array}{l}<10 / \text { day } \\
>10 / \text { day }\end{array}$ & $\%$ & $\begin{array}{l}12 \cdot 2 \\
32 \cdot 9\end{array}$ & $\begin{array}{l}17.9 \\
28 \cdot 6\end{array}$ & $\begin{array}{l}11 \cdot 3 \\
23 \cdot 8\end{array}$ & $\begin{array}{l}0.59 \\
0.56\end{array}$ \\
\hline $\begin{array}{l}>10 / \text { day } \\
\text { Alcohol, non-user }\end{array}$ & $\begin{array}{l}\% \\
\%\end{array}$ & $86 \cdot 6$ & $91 \cdot 7$ & $\begin{array}{l}23 \cdot 8 \\
90 \cdot 0\end{array}$ & $\begin{array}{l}0 \cdot 56 \\
0.56\end{array}$ \\
\hline $\begin{array}{l}\text { Alcohol, non-user } \\
<50 \text { g/day }\end{array}$ & $\begin{array}{l}\% \\
\%\end{array}$ & $7 \cdot 3$ & $3 \cdot 6$ & $\begin{array}{r}90 \cdot 0 \\
5 \cdot 0\end{array}$ & $0 \cdot 56$ \\
\hline $\begin{array}{l}<50 \text { g/day } \\
>50 \text { g/day }\end{array}$ & $\%$ & $3 \cdot 6$ & $4 \cdot 8$ & $\begin{array}{l}5 \cdot 0 \\
5 \cdot 0\end{array}$ & $0 \cdot 56$ \\
\hline $\begin{array}{l}>50 \mathrm{~g} / \text { day } \\
\text { Analgesic, non-user }\end{array}$ & $\begin{array}{l}\% \\
\%\end{array}$ & $89 \cdot 0$ & $85 \cdot 7$ & $\begin{array}{r}5 \cdot 0 \\
86 \cdot 3\end{array}$ & 0.92 \\
\hline $\begin{array}{l}\text { Analgesic, non-user } \\
\text { once/month }\end{array}$ & $\begin{array}{l}\% \\
\%\end{array}$ & $8 \cdot 5$ & $9 \cdot 5$ & $\begin{array}{l}86 \cdot 3 \\
13 \cdot 8\end{array}$ & $\begin{array}{l}0 \cdot 80 \\
0.52\end{array}$ \\
\hline $\begin{array}{l}\text { once/month } \\
\text { once/week }\end{array}$ & $\%$ & $2 \cdot 4$ & $4 \cdot 8$ & $\begin{array}{c}13 \cdot 8 \\
0\end{array}$ & $\begin{array}{l}0 \cdot 32 \\
0 \cdot 14\end{array}$ \\
\hline Familial dyspepsia & $\%$ & $39 \cdot 0$ & $40 \cdot 0$ & $44 \cdot 0$ & 0.45 \\
\hline strength & $0-3$ & $0 \cdot 5 \pm 0 \cdot 1$ & $0 \cdot 6 \pm 0 \cdot 1$ & $0 \cdot 6 \pm 0 \cdot 1$ & $0 \cdot 30$ \\
\hline Body weight & $\mathrm{kg}$ & $55 \cdot 3 \pm 0 \cdot 9$ & $56 \cdot 18 \pm 1 \cdot()$ & $53 \cdot 25 \pm 1 \cdot 0$ & $0 \cdot 10$ \\
\hline Blood group $\mathrm{O}$ & $\%$ & 32 & 38 & 34 & 0.99 \\
\hline \multicolumn{6}{|l|}{ Physiological } \\
\hline $\begin{array}{l}\text { BAO* }^{*} \\
\text { MAO* }^{*}\end{array}$ & $\begin{array}{l}\mathrm{mmol} / \mathrm{h} \\
\mathrm{mmol} / \mathrm{h}\end{array}$ & $\begin{array}{r}3 \cdot 2 \pm 0 \cdot 4 \\
26 \cdot 7 \pm 1 \cdot 3\end{array}$ & $\begin{array}{r}3 \cdot \pm \pm 0 \cdot 3 \\
25 \cdot 9 \pm 1 \cdot 2\end{array}$ & $\begin{array}{r}3 \cdot 0 \pm 0 \cdot 3 \\
24 \cdot() \pm 1 \cdot()\end{array}$ & $\begin{array}{l}0 \cdot / 0 \\
0 \cdot 12\end{array}$ \\
\hline $\begin{array}{l}\mathrm{MAO}^{*} \\
\mathrm{MAO} / \mathrm{kg}\end{array}$ & $\begin{array}{l}\mathrm{mmol} / \mathrm{h} \\
\mathrm{mmol} / \mathrm{h} / \mathrm{kg}\end{array}$ & $0 \cdot 48 \pm 0 \cdot 02$ & $0 \cdot 48 \pm 0 \cdot(12$ & $0 \cdot 46 \pm 0 \cdot 02$ & $0 \cdot 25$ \\
\hline Hypersecretor & $\begin{array}{l}\mathrm{mmol} / \mathrm{h} / \mathrm{kg} \\
\%\end{array}$ & $42 \cdot 7$ & $39 \cdot 7$ & $47 \cdot 5$ & $0 \cdot 21$ \\
\hline $\mathrm{D}_{50 \mathrm{~K}^{*}}$ & $\mathrm{ng} / \mathrm{kg} / \mathrm{h}$ & $131 \cdot 4 \pm 18 \cdot 8$ & $107 \cdot 9 \pm 10 \cdot 9$ & $145 \cdot 2 \pm 20 \cdot 6$ & $0 \cdot 51$ \\
\hline Low $\mathrm{D}_{50 \mathrm{C}}$ & $\%$ & $42 \cdot 3$ & $57 \cdot 1$ & $49 \cdot 3$ & $0 \cdot 22$ \\
\hline Fasting gastrin* & $\mathrm{nmol} / \mathrm{l}$ & $49 \cdot 4 \pm 7 \cdot 7$ & $42 \cdot 3 \pm 2 \cdot 4$ & $44 \cdot 1 \pm 2 \cdot 9$ & $0 \cdot 17$ \\
\hline 2-h postprandial* gastrin & $\mathrm{nmol} . \mathrm{min} / \mathrm{l}$ & $9 \cdot 6 \pm 1 \cdot 0$ & $9 \cdot 1 \pm 0 \cdot 74$ & $10 \cdot 1 \pm 0 \cdot 6$ & $0 \cdot 10$ \\
\hline \multicolumn{6}{|l|}{ Endoscopic } \\
\hline Ulcer site anterior & $\%$ & $53 \cdot 7$ & $41 \cdot 7$ & $45 \cdot 0$ & $0 \cdot 33$ \\
\hline posterior & $\%$ & $8 \cdot 5$ & $8 \cdot 3$ & $10 \cdot 0$ & 0.97 \\
\hline roof & $\%$ & $14 \cdot 6$ & $31 \cdot 0$ & $28 \cdot 8$ & 0.06 \\
\hline floor & $\%$ & $15 \cdot 9$ & $8 \cdot 3$ & $8 \cdot 8$ & $0 \cdot 37$ \\
\hline apex & $\%$ & $7 \cdot 9$ & $10 \cdot 7$ & $7 \cdot 5$ & $0 \cdot 83$ \\
\hline Multiple ulcer & $\%$ & $23 \cdot 1$ & $14 \cdot 0$ & $15 \cdot 0$ & 0.52 \\
\hline Index ulcer diameter & $\mathrm{mm}$ & $7 \cdot 1 \pm 0 \cdot 5$ & $7 \cdot 0 \pm 0 \cdot 4$ & $6 \cdot 4 \pm 0.4$ & 0.09 \\
\hline depth & $\mathrm{mm}$ & $1 \cdot 5 \pm 0 \cdot 1$ & $1 \cdot 3 \pm 0 \cdot 1$ & $1 \cdot 2 \pm 0 \cdot 1$ & $0 \cdot 10$ \\
\hline Inflammation & $0-3$ & $0 \cdot 89 \pm 0 \cdot 09$ & $0 \cdot 64 \pm 0 \cdot 08$ & $0 \cdot 91 \pm 0 \cdot 10$ & 0.07 \\
\hline Deformity & $0-3$ & $0 \cdot 47 \pm 0 \cdot 08$ & $0 \cdot 68 \pm 0 \cdot 09$ & $0 \cdot 61 \pm 0.08$ & $0 \cdot 21$ \\
\hline
\end{tabular}


interfering $=2$, requiring immediate medical attention such as attending the casualty $=3$. Familial dyspepsia was considered present when patient indicated that ulcer dyspepsia, gastrointestinal bleeding, perforation, and/or gastric surgery had occurred in a first degree relative; this was scored as nil $=0$, one first degree relative $=1$, two $=2$, three or more or both parents $=3$. Stress at work was scored subjectively by patient as 0 to 3 and included work pressure and/or labour intensity of the job. Neurosis was scored according to the number of neurotic traits present with a maximum of 3 (insomnia, tension headache, palpitation, hand tremors, non-postural dizzy spells). Habitual cigarette smoking was scored as nil $=0,<10 /$ day $=1$, and $>10$ /day $=2$. The majority of smokers had smoked continuously for $>10$ years, and all smokers had this habit for at least five years. Habitual alcohol consumption for at least five years was scored as nil $=0$, estimated alcohol $<50 \mathrm{~g} /$ day $=1,>50 \mathrm{~g} /$ day $=$ 2. Habitual analgesic consumption for at least one year was scored as nil $=0,1$ dose $/$ month $=1$, at least 1 dose/week $=2$; analgesics included aspirin, non-steroidal anti-inflammatory agents, and the many forms of patent Chinese herbal medicine, the nature of which was mostly undefined. The patients were not told to stop their smoking, alcoholic, or analgesic habits, but were told that these might be harmful to ulcer healing. At subsequent visits, these habits were assessed by direct questioning and the consumption per day was recorded. The consumption during treatment was scored at the end of the trial as nil to begin with $=0$, withdrawn completely $=1$, reduced by $>50 \%=2$, and unchanged $=3$.

In addition, before and at each subsequent visit, the following non-ulcer symptoms were recorded: loose motions, constipation, skin rash, dizziness, headache, palpitation, blurring of vision, dryness of mouth, gynaecomastia, or galactorrhoea, impotence, and libido (amount of sexual intercourse over the past week). Each patient was also asked to record on a tabulated diary card the occurrence of pain, its severity and the number of antacid tablets consumed.

\section{PHYSIOLOGICAL CHARACTERISTICS}

The methodologies were described in detail previously. ${ }^{7}$ Before the start of treatment, fasting and two hour serum gstrin measurements after a standard meal were made on one morning, and basal acid output (BAO), maximal acid output (MAO), and dose of pentagastrin required for half MAO and corrected for BAO $\left(D_{50}\right)$ were measured on another morning from a pentagastrin dose-response test. $D_{50 \mathrm{C}}$ was taken to represent the sensitivity of the parietal cells. Hypersecretor was defined as a patient having $\mathrm{MAO} / \mathrm{kg}$ total body weight above 2 $\mathrm{SD}$ of the mean of normal as established previously in 100 normal Chinese subjects. Low $\mathrm{D}_{50 \mathrm{C}}$ was defined as less than $50 \mathrm{ng} / \mathrm{kg} / \mathrm{h}$, as established previously in 38 normal controls. ${ }^{8}$

\section{ENDOSCOPIC CHARACTERISTICS}

Endoscopy was carried out with a forward viewing panendoscope (Olympus GIF-Q or P) within 72 hours before the start of treatment, at the end of four weeks of treatment, and, if the ulcer remained unhealed, at the end of eight weeks. Patient would be withdrawn from the study if the ulcer was still unhealed, or if complications or uncontrolled symptoms developed in the course of the study. As far as possible each patient was endoscoped throughout the study by the same author who was unaware of the patient's form of treatment and clinical progress. The diameters and depth of the ulcer were estimated using the tips of the biopsy forceps. Patients were excluded from the study if the longest diameters of their ulcers were less than $3 \mathrm{~mm}$ or greater than 25 $\mathrm{mm}$. The endoscopic characteristics as listed in Table 1 were recorded. Ulcer site was described as anterior, posterior, floor, roof and apex (near the exit) of the duodenal bulb. The degree of surrounding inflammation was scored as gross hyperaemia, granularity, and/or oedema $=3$, moderate $=2$, mild $=1$, absent $=0$. The degree of deformity of the duodenal bulb was scored: actual narrowing of entrance or exit of the duodenal bulb by scar but still admitting the (GIF-P) endoscope (external diameter $=9 \mathrm{~mm})=3$, bilateral deformity $=2$, unilateral deformity of bulb $=1$, absent $=0$. The findings at subsequent endoscopies were compared with those observed at the initial endoscopy, and the patient was classified immediately as healed (complete disappearance of ulcer with or without residual inflammation usually in the form of hyperaemia and granularity), or unhealed (persistence of ulcer, however small).

\section{STUDY DESIGN}

All patients were treated on an ambulant basis. They were randomised to receive one of three oral forms of treatment: (i) cimetidine (Smith Kline \& French Laboratories) $200 \mathrm{mg}$ tds immediately before breakfast, lunch, and supper, (ii) cimetidine $600 \mathrm{mg}$ at bedtime, and (iii) cimetidine $200 \mathrm{mg}$ tds immediately before the three meals and $400 \mathrm{mg}$ at bedtime. At each visit each patient was also given 40 antacid tablets (Gelusil, containing magnesium trisilicate $500 \mathrm{mg}$ and dried aluminium hydroxide gel 250 $\mathrm{mg}$ with a neutralising capacity of $6 \mathrm{Meq}$ of $\mathrm{HC} 1$ ), and was asked to chew one or two tablets for pain relief. Treatment was ended when patient's ulcer 
completely healed at weeks four or eight.

Patients were instructed to eat no more than three regular meals per day and not to take any other medicine without notifying the ulcer clinic sister, and to return at each visit any remaining medications, which would then be counted.

\section{STATISTICAL ANALYSIS}

On the assumption that $80 \%$ of the patients treated with cimetidine $1 \mathrm{~g}^{\mathrm{g}}$ daily $^{7}$ and $60 \%$ of the patients treated with either the meal time or bedtime regimens would heal after four weeks, we calculated that we should include 83 subjects in each group to show a difference of $20 \%$ with a Type I error of 0.05 and a type II error of $0 \cdot 20$ (one-sided test). ${ }^{9}$ Chi square test with Yate's correction, and one way analysis of variance, were used as appropriate. ${ }^{10}$ Values were expressed as mean $\pm S E$, and $p$ values of less than 0.05 were considered significant.

The criterion for statistical significance used for analysis of factors affecting ulcer healing was not the most stringent, but it served well to unmask and therefore bring to our attention any possible factor that might affect healing. To avoid possible spurious results, the same phenomenon, such as cigarette smoking or analgesic use, was often analysed in more than one way - for example, per cent smokers, average consumption, and withdrawal score, and as can be seen in Table 2, a significant difference was found in more than one methods of analysis, indicating that the phenomenon was unlikely to be a spurious finding.

\section{Results}

\section{PATIENTS}

No significant difference in each of the 45 patient characteristics listed in Table 1 could be detected between the two groups.

\section{EXCLUSION}

Two patients on meal time regimen and four patients on the standard regimen defaulted at week 4. They were excluded from analysis. No patient on the bedtime regimen defaulted.

\section{COMPLIANCE AND SYMPTOMATIC RESPONSE}

Mean numbers of treatment tablets omitted per week in the meal time cimetidine group $(0.2$ to 1.5$)$ bedtime cimetidine group $(0.02$ to 0.8$)$, and $1 \mathrm{~g}$ daily cimetidine group $(0.2$ to 1.7$)$ were not significantly different during the eight week period. Mean number of Gelusil tablets taken per week in the three groups were not statistically different in the first four weeks (meal time: $2 \cdot 1$ to $3 \cdot 3$; bedtime $1 \cdot 7$ to $4 \cdot 0,1 \mathrm{~g}$ daily: 1.8 to $3 \cdot 8$ ) as well as in the last four weeks (meal time: 0.2 to $0 \cdot 6$; bedtime: 0.2 to $0.7 ; 1 \mathrm{~g}$ daily $0 \cdot 2$ to $0 \cdot 7)$. Pain score was not significantly different among the three groups at week 4 (mean score of 0.4 for each group) and at week 8 (mean score of 0.02 for meal time regimen, 0.05 for bedtime regimen and 0.03 for standard regimen). Similar proportion of patients became pain-free among the three groups at week $4(82.5 \%, 75.0 \%$, $80.0 \%$ respectively) and at week $8(100 \%, 97.5 \%$, $97.5 \%$ respectively).

Table 2 Factors affecting healing of duodenal ulcer treated for 4 weeks with 3 regimens of cimetidine: meal-time (200 mg tds), bedtime $(600 \mathrm{mg})$, and standard $(200 \mathrm{mg}$ tds with meals and $400 \mathrm{mg}$ at bedtime $) . H=$ healed, NH=not healed. Values are expressed as mean $\pm S E$. Asterisk indicates values that were log transformed before statistical analysis.

\begin{tabular}{|c|c|c|c|c|c|c|c|c|c|c|}
\hline & & \multicolumn{3}{|l|}{$\begin{array}{l}\text { Meal time } \\
200 \mathrm{mg} t d s\end{array}$} & \multicolumn{3}{|l|}{$\begin{array}{l}\text { Bedtime } \\
600 \mathrm{mg}\end{array}$} & \multicolumn{3}{|l|}{$\begin{array}{l}\text { Standard } \\
l \mathrm{~g} \text { daily }\end{array}$} \\
\hline & & $H$ & $N H$ & $p<$ & $H$ & $\mathrm{NH}$ & $p<$ & $H$ & $N H$ & $p<$ \\
\hline & & $51(62 \cdot 2)^{\mathrm{a}}$ & 31 & - & $53(63 \cdot 1)^{b}$ & 31 & - & $62(77 \cdot 5)^{c}$ & 18 & - \\
\hline \multirow{4}{*}{$\begin{array}{l}\text { Cigarette smoking } \\
\text { consumption } \\
>10 / \text { day } \\
\text { withdrawal }\end{array}$} & $\%$ & $35 \cdot 3$ & $61 \cdot 3$ & 0.02 & $47 \cdot 2$ & $45 \cdot 2$ & 0.77 & $30 \cdot 6$ & $50 \cdot 0$ & $0 \cdot 22$ \\
\hline & $0-2$ & $0 \cdot 6 \pm 0 \cdot 1$ & $1 \cdot 1 \pm 0 \cdot 2$ & 0.01 & $0 \cdot 5 \pm 0 \cdot 6$ & $0 \cdot 5 \pm 0 \cdot 1$ & $0 \cdot 86$ & $0 \cdot 5 \pm 0 \cdot 1$ & $0.8 \pm 0.2$ & $0 \cdot 17$ \\
\hline & $\%$ & $23 \cdot 5$ & 48.4 & 0.01 & $30 \cdot 2$ & $25 \cdot 8$ & $0 \cdot 61$ & $21 \cdot 0$ & $33 \cdot 3$ & $0 \cdot 30$ \\
\hline & $3-0$ & $0 \cdot 9 \pm 0 \cdot 2$ & $1 \cdot 7 \pm 0 \cdot 3$ & 0.01 & $1 \cdot 1 \pm 1 \cdot 1$ & $1 \cdot 3 \pm 0 \cdot 3$ & 0.59 & $0 \cdot 8 \pm 0 \cdot 2$ & $1 \cdot 5 \pm 0 \cdot 3$ & $0 \cdot 06$ \\
\hline \multirow{3}{*}{$\begin{array}{l}\text { Analgesics } \\
\text { consumption } \\
\text { withdrawal }\end{array}$} & $\%$ & 0 & $17 \cdot 6$ & $0 \cdot 01$ & $3 \cdot 2$ & $20 \cdot 8$ & 0.02 & $14 \cdot 5$ & $11 \cdot 1$ & 1.00 \\
\hline & $0-2$ & 0 & $0 \cdot 2 \pm 0 \cdot 1$ & 0.02 & $0 \cdot 03 \pm 0$ & $0 \cdot 3 \pm 0 \cdot 1$ & 0.03 & $0 \cdot 2 \pm 0 \cdot 1$ & $0 \cdot 1 \pm 0$ & 0.72 \\
\hline & $3-0$ & 0 & $0 \cdot 3 \pm 0 \cdot 03$ & $0 \cdot 03$ & $0 \cdot 02 \pm 0$ & $0 \cdot 3 \pm 0 \cdot 1$ & 0.04 & $0 \cdot 2 \pm 0$ & $0 \cdot 2 \pm 0 \cdot 1$ & $0 \cdot 81$ \\
\hline Symptom period & days & $21 \cdot 0 \pm 6 \cdot 0$ & $22 \cdot 0 \pm 7 \cdot 2$ & 0.91 & $36 \cdot 0 \pm 10 \cdot 4$ & $17 \cdot 6 \pm 4 \cdot 4$ & $0 \cdot 01$ & $29 \cdot 7 \pm 8 \cdot 6$ & $27 \cdot 1 \pm 10 \cdot 2$ & $0 \cdot 88$ \\
\hline Basal acid output ${ }^{*}$ & $\mathrm{mmol} / \mathrm{h}$ & $3 \cdot 0 \pm 0.4$ & $3 \cdot 5 \pm 0 \cdot 6$ & $0 \cdot 03$ & $3 \cdot 4 \pm 0 \cdot 3$ & $2 \cdot 9 \pm 0.4$ & 0.05 & $2 \cdot 9 \pm 0 \cdot 4$ & $3 \cdot 4 \pm 0 \cdot 4$ & 0.01 \\
\hline \multirow[t]{2}{*}{ Maximal acid output* } & $\mathrm{mmol} / \mathrm{h}$ & $24 \cdot 6 \pm 1 \cdot 3$ & $30 \cdot 3 \pm 2 \cdot 5$ & 0.06 & $23 \cdot 7 \pm 0 \cdot 5$ & $29 \cdot 8 \pm 2 \cdot 1$ & 0.05 & $22 \cdot 9 \pm 1 \cdot 1$ & $26 \cdot 6 \pm 1.9$ & 0.05 \\
\hline & $\mathrm{mmol} / \mathrm{h} / \mathrm{kg}$ & $0 \cdot 45 \pm 0 \cdot 02$ & $0.53 \pm 0.04$ & $0 \cdot 01$ & $0 \cdot 46 \pm 0 \cdot 03$ & $0 \cdot 51 \pm 0 \cdot 04$ & 0.06 & $0.43 \pm 0.02$ & $0.55 \pm 0.04$ & 0.01 \\
\hline Postprandial gastrin* & nmol.min/l & $10 \cdot 4 \pm 0 \cdot 9$ & $8 \cdot 3 \pm 0 \cdot 6$ & 0.01 & $8 \cdot 6 \pm 0 \cdot 7$ & $10 \cdot 1 \pm 1 \cdot 6$ & 0.22 & $10 \cdot 6 \pm 0 \cdot 7$ & $8 \cdot 5 \pm 0 \cdot 6$ & 0.02 \\
\hline Ulcer diameter & $\mathrm{mm}$ & $6.9 \pm 0.7$ & $7 \cdot 3 \pm 0 \cdot 6$ & 0.02 & $6 \cdot 5 \pm 0 \cdot 5$ & $7 \cdot 8 \pm 0 \cdot 7$ & 0.02 & $6 \cdot 0 \pm 0 \cdot 3$ & $7 \cdot 8 \pm 1 \cdot 2$ & 0.01 \\
\hline
\end{tabular}

a c $\mathrm{p}<0.05,{ }^{\text {b }} \mathrm{p}<0.05$ 
HEALING

When the three groups (meal time, bedtime, and standard regimens) were compared with respect to healing at weeks four $(62.2 \%, 63.1 \%$, and $77.5 \%$ respectively) and eight $(86.6 \%, 83.3 \%$, a nd $91.2 \%)$, no significant difference was obtained among the three regimens. $\left(\chi^{2}=5.43, p<0.06 ; \chi^{2}=2 \cdot 29\right.$, $\mathrm{p}<0.32$ respectively). There was also no significant difference when the meal time and bedtime regimens were compared. When these two regimens were individually compared with the standard regimen of $1 \mathrm{~g}$ daily, however, a significant $(\mathrm{p}<0.05)$ difference was observed at week four but not at week eight. (Table 2).

\section{FACTORS AFFECTING HEALING}

Each of the 45 factors listed in Table 1 was analysed. Those which significantly $(p<0.05)$ separated healing from non-healing were listed in Table 2. Patients who healed with the bedtime regimen, but not those who healed with the meal time regimen, had significantly longer symptom period before treatment was started. With meal time but not with bedtime cimetidine, cigarette smoking, heavy smoking, and failure to abstain from smoking during treatment were significantly more associated with non-healing. With both meal time and bedtime regimens, habitual use of analgesics were unfavourable to healing, whereas abstinence during treatment was favourable. The use of analgesics and their abstinence, however, had no effect on healing with the standard regimen. With meal time cimetidine, basal acid output was significantly higher but meal stimulated serum gastrin was significantly lower in patients with unhealed than with healed ulcer, whereas with bedtime cimetidine, the reverse was true. With both regimens, maximal acid output was higher and ulcer diameter bigger in patients with unhealed than in those with healed ulcers.

\section{SIDE EFFECTS}

No undue symptoms, or abnormal haematological or biochemical results were noted before, during and at the end of the study.

\section{Discussion}

The healing rates of meal time $(200 \mathrm{mg} \mathrm{tds})$ and bedtime $(600 \mathrm{mg})$ cimetidine are practically identical, and are approximately $62 \%$ and $85 \%$ at weeks four and eight respectively. These healing rates compare favourably with the $77 \%$ and $91 \%$ respectively of the standard cimetidine regimen of $1 \mathrm{~g}$ daily taken in divided doses at meal time and bedtime. The differences from the standard regimen at four weeks, however, just reach statistical significance because of the large number of patients involved. While the healing rates of the meal time and bedtime regimens may not be ideal enough to be recommended for general use, they are substantial enough to support the importance of reducing the meal stimulated and nocturnal acid secretions in the healing of duodenal ulcer. It is to be noted that we have shown previously that cimetidine $500 \mathrm{mg}$ daily in divided doses have identical healing rates as $1 \mathrm{~g}$ daily in divided doses in Chinese patients with duodenal ulcer, and that cimetidine $100 \mathrm{mg}$ and 200 $\mathrm{mg}$ (IVI bolus) have identical effects on pentagastrin dose-response curves. ${ }^{7}$ Cimetidine $600 \mathrm{mg}$ as used in the present study therefore represents a large dose for the Chinese patients with duodenal ulcer. Our findings also suggest that reducing postprandial and nocturnal acid secretion are equally important in the healing of duodenal ulcer, and that the ideal regimen for ulcer healing should be able to achieve both.

Much evidence has accumulated to indicate that acid hypersecretion in duodenal ulcer is heterogenous in origin. As recently reviewed, ${ }^{11}$ increased basal acid output, excessive cephalic acid response, abnormally large maximal acid secretory capacity, hypersensitivity to gastrin, postprandial hypergastrinaemia, and abnormal autoregulation of gastrin release are well described physiological abnormalities that could lead to acid hypertension, alone or in combination, in response to a meal or during the night. Individually, each of these physiological abnormality occurs in approximately $30 \%$ (range being $10 \%$ to $50 \%$ ) of duodenal ulcer patients. However, an abnormally high meal stimulated acid secretion and nocturnal acid secretion can be demonstrated in over $60 \%$ of patients in the literature, although reports of these two measurements of acid secretion are scanty. ${ }^{11}$ These suggest that abnormally high meal stimulated and nocturnal acid secretions are common abnormalities in duodenal ulcer and explain why therapeutic reduction of these secretions would result in high healing rates.

When the two regimens and the standard $1 \mathrm{~g}$ daily regimen were analysed for factors that affected healing, cigarette smoking was found to adversely affect healing with the meal time regimen but not with the bedtime or standard regimens. This suggests that the adverse effect of smoking on healing may be related to nocturnal acid secretion, so that once this is reduced, the adverse effect disappears. One possible explanation is that smoking facilitates nocturnal acid secretion. There is no evidence to support this, however, although smoking has been shown to increase basal acid output. ${ }^{12}$ Another explanation is that smoking impairs the healing 
process which takes place during sleep, and that reduction of nocturnal acid secretion is permissive to the healing process. The effect of "smoking on healing, and the relationship of healing and nocturnal acid secretion remain to be defined.

The habitual use of analgesics was also unfavourable to healing with the meal time regimen, but this was true also with the bedtime regimen. Furthermore, once analgesics were withdrawn a reverse of the harmful effects became obvious. These findings suggest that analgesics impair healing during the night and also during the day, but can also be explained if analgesics facilitate acid secretion, although there is no evidence to support such an action. Interestingly, with the standard regimen, the adverse effects of analgesics disappeared, and whether analgesics were withdrawn or not during treatment became unimportant. These findings firstly support that a healing process takes place at daytime, possibly after meals, and also at night time, possibly during sleep, and secondly indicate that reduction of meal time and nocturnal acid secretions plays an important permissive role in healing. These findings also suggest that if analgesics cannot be withdrawn during ulcer treatment, it is important to ensure a reduction of both daytime and night time acid secretions.

Responders to the meal time regimen had higher meal stimulated serum gastrin but lower basal acid output, whereas responders to the bedtime regimen had the reverse, indicating that these two groups of responders are pathophysiologically different. The reasons for these findings are not clear. One possible explanation is that patients with higher basal acid output may have higher nocturnal acid secretion ${ }^{13}$ and are better controlled with bedtime cimetidine, while those with higher meal-stimulated gastrin may have higher meal stimulated acid secretion $^{14}$ and are better controlled with meal time cimetidine. Further studies on nocturnal and postprandial acid secretions in duodenal ulcers are warranted.

The findings that patients with higher maximal acid output and larger ulcer diameter responded less well to all three regimens agree with previous studies using $1 \mathrm{~g}$ daily cimetidine. ${ }^{715}$

In summary, reducing postprandial or nocturnal acid secretions results in the healing of duodenal ulcer in $60 \%$ to $80 \%$ of patients in four to eight weeks. Comparison of the meal time and bedtime regimens has given rise to an opportunity to understand better the healing factors in relation to the reduction of postprandial and nocturnal acid secretions.

This study was supported by the Peptic Ulcer
Research Fund (311/041/0372) and University Grants (311/030/8009/31, 311/030/8010/12, 335/041/ $0006,311 / 030 / 8010 / 69)$ of the University of Hong Kong. The authors are grateful to $\mathrm{M}$ Chong, $\mathrm{B} \mathrm{Ng}, \mathrm{J}$ Wong, $\mathrm{P}$ Leung and $\mathrm{A}$ Choi for nursing assistance, and to $\mathrm{J}$ Watt for secretarial assistance. This work was presented in part at the American Gastroenterological Association Meeting, May 1984, New Orleans.

\section{References}

1 Peterson WL, Sturdevant RAL, Frankl DH, et al. Healing of duodenal ulcer with an antacid regimen. $N$ Engl J Med 1977; 297 341-5.

2 Lam SK, Lam KC, Lai CL, Yeung CK, Yam LYC, Wong WS. Treatment of duodenal ulcer with antacid and sulpiride. A double-blind controlled study. Gastroenterology 1979; 76: 315-22.

3 Lam SK, Lai CL, Lee NW, et al. Effective healing of duodenal ulcer with single night time dose of oxmetidine - a double blind controlled study. Gastroenterology 1983; 84: 1221.

4 Ireland A, Colin-Jones DG, Gear P, et al. Ranitidine $150 \mathrm{mg}$ twice daily vs $300 \mathrm{mg}$ nightly in the treatment of duodenal ulcers. Lancet 1984; 2: 274-5.

5 Misiewicz JJ. Histamine $\mathrm{H}_{2}$-receptor antagonists in short- and long-term treatment of duodenal ulcer. In: Holtermuller $\mathrm{KH}$, Malagelada JR, eds. Advances in ulcer disease. Amsterdam, Oxford, Princeton: Excepta Medica, 1980; 318-29.

6 Lam SK, Koo J, Sircus W. Early and late onset duodenal ulcers in Chinese and Scots. Scand J Gastroenterol 1983; 18: 651-8.

7 Lam SK, Koo J. Accurate prediction of duodenal-ulcer healing rate by discriminant analysis. Gastroenterology 1983; 85: 403-12.

8 Lam SK, Koo J. Gastrin sensitivity in duodenal ulcer. Gut 1985; 26: 485-90.

9 Fleiss JL. Statistical methods for rates and proportions. New York, Wiley, 1973.

10 Snedecor CW, Cochran WG. Statistical methods. 6th ed. Ames. Iowa: Iowa State University Press, 1967.

11 Lam SK. Pathogenesis and pathophysiology of duodenal ulcer. In: Isenberg JI, Johanssen C, eds. Peptic ulcer disease. Clinics in Gastroenterology. London, Philadelphia, Toronto; W B Saunders, 1984; 13: 447-71.

12 Murthy SNS, Dinoso VP, Clearfield HR, Cheng WY. Serial $\mathrm{pH}$ changes in the duodenal bulb during smoking. Gastroenterology 1978; 75: 1-4.

13 Levin E, Kirsner JB, Palmer WL. A simple measure of gastric secretion in man. Comparison of one hour basal secretion, histamine secretion and twelve hour nocturnal gastric secretion. Gastroenterology 1952; 19: 88-98.

14 Lam SK, Isenberg JI, Grossman MI, Lane WH, Walsh 
JH. Gastric acid secretion is abnormally sensitive to endogenous gastrin released after peptone test meals in duodenal ulcer patients. J Clin Invest 1980; 65: 555-62.
15 Binder HJ, Cocco A, Crossley RJ, et al. Cimetidine in the treatment of duodenal ulcer. A multicenter double blind study. Gastroenterology 1978; 74: 380-8. 